\title{
Staphylococcal Infection
}

National Cancer Institute

\section{Source}

National Cancer Institute. Staphylococcal Infection. NCI Thesaurus. Code C35038.

infection by Staphylococcus. 